\title{
SLENDER THIN-WALLED BOX COLUMNS SUBJECTED TO COMPRESSION AND BENDING
}

\author{
Luka Pavlovčič ${ }^{1}$, Bernadette Froschmeier ${ }^{2}$, Ulrike Kuhlmann ${ }^{3}$, Darko Beg ${ }^{4}$ \\ ${ }^{1,4}$ University of Ljubljana, Faculty of Civil and Geodetic Engineering, Jamova 2, 1000 Ljubljana, Slovenia, \\ ${ }^{2,3}$ University of Stuttgart, Institute of Structural Design, Pfaffenwaldring 7, 70569 Stuttgart, Germany \\ E-mail: ${ }^{1} l u k a . p a v l o v c i c @ f g g . u n i-l j . s i ;{ }^{2}$ Bernadette.Froschmeier@ke.uni-stuttgart.de; \\ ${ }^{3}$ u.Kuhlmann@ke.uni-stuttgart.de; ${ }^{4}$ darko.beg@fgg.uni-lj.si \\ Received 05 Oct. 2009; accepted 17 Dec. 2009
}

\begin{abstract}
This paper deals with tests on slender thin-walled box columns, susceptible to instability of both types: to global Euler buckling as well as to local buckling of steel plates. Eight full-scale tests were carried out with different global slenderness of welded and cold-formed columns subjected to centric and eccentric compression. For the purpose of profound numerical simulations of tests, material properties were also tested, and the initial column geometry and residual stresses were carefully measured. The results of FEA simulations show good agreement with the test results. On verified numerical model the influence of different initial imperfections was studied.
\end{abstract}

Keywords: slender columns, box profiles, cold-formed sections, stability, buckling, tests, FEA, numerical simulations, initial imperfections, residual stresses.

\section{Introduction}

Economical design of steel and composite bridges leads to lightweight structures made from slender elements, possibly fabricated from relatively thin plates. Thinwalled box profiles may be applied for arches or truss elements of bridges or as slender columns in office and industry buildings. Loaded in compression, the slender plates of the elements may be locally buckled and if due to e.g. aesthetic reasons such elements are also globally slender, the column may also fail in global Euler buckling mode. This leads to the instability problem of thin-walled slender columns (Fig. 1) where local buckling weakens the overall stiffness and reduces the global buckling load.

The latest Eurocode provisions EN 1993-1-1 (2005), EN 1993-1-5 (2005) cover the problem of column stability by using well-known European buckling curves (EBC) and non-dimensional global slenderness $\bar{\lambda}_{G L}$. The effect of local plate buckling of slender (class 4 ) cross-sections can be considered with the determination of effective cross-section based on the Winter formula and local plate slenderness $\bar{\lambda}_{l o c}$. The Eurocode procedure for combined instability introduces a modified non-dimensional global slenderness - equation (1), which includes the effective cross-sectional area $A_{\text {eff, while global slenderness }} \bar{\lambda}_{G L}$ is evaluated based on gross cross-section properties. The load-carrying capacity of welded box profiles should be then determined from EBC $b$.

$$
\bar{\lambda}_{G L, \text { class } 4}=\sqrt{\frac{A_{e f f}}{A}} \cdot \frac{L_{c r}}{i \lambda_{1}}=\sqrt{\frac{A_{e f f}}{A}} \cdot \bar{\lambda}_{G L} .
$$

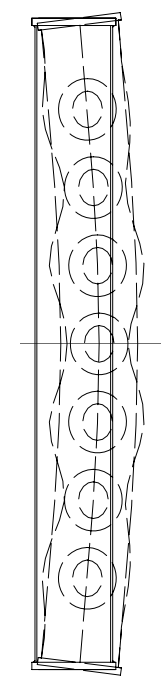

Fig. 1. Interaction of global and local buckling of box column (Detzel 2006)

This procedure was well calibrated especially for I-profile columns. Some recent investigations (Rusch 2000; Brune 2000; Detzel 2006) have shown that this procedure leads to not very satisfying resistance estimation, especially for the case of thin-walled columns. This motivated a research project, which produced a new proposal for the capacity determination of welded slender thin-walled box columns subjected to pure compression (Kuhlmann and Detzel 2004; Detzel 2006; Degée et al. 2008). Based on six tests and an extensive numerical parametric study the proposed method promotes a modi- 
fied definition of non-dimensional global slenderness together with the use of more favourable EBC $a$ instead of $b$ for welded box profiles.

The present research continues the preceding investigations on even wider range of global and local slenderness, on columns under combined compression and bending and with the additional study on cold-formed box profiles. The research combines experimental work and numerical studies. Eight full-scale tests served for the verification of numerical models on which a wider parametric study will be carried out.

This paper presents the test results with all accompanying tensile material tests and measurements of initial imperfections, which all provided the necessary data for a proper numerical simulation. Finite element analysis (FEA) will be presented with the focus on the implementation of various imperfections. The comparison of numerical and test results will be discussed. Since the imperfections appeared to have a significant impact on the load-carrying capacity and column behaviour, the influence of different measured imperfections will be finally analysed separately and in combinations.

\section{Experimental work}

\subsection{Full-scale tests}

\subsubsection{Selection of specimens}

All tests were carried out in the Laboratory of Otto-Graf Institute, MPA Stuttgart at the University of Stuttgart. Test description and result analysis are thoroughly presented in the test report (Pavlovčič et al. 2009). From eight full-scale tests 4 were loaded in pure compression and 4 in combined compression and bending, by varying load eccentricity $e_{y}$. Among centric tests two higher columns $\left(L_{u}=5.2 \mathrm{~m}\right)$ were planned to fail predominantly in global Euler buckling and two shorter $\left(L_{u}=4.0 \mathrm{~m}\right)$ were susceptible to combined global and local buckling. Tests from the previous research (Kuhlmann and Detzel 2004) collapsed predominantly in local buckling mode. Beside welded columns (W) also cold-formed profiles (CF) were tested with similar cross-section dimensions (Fig. 2) and the same local plate slenderness. These cold formed profiles were built up of two cold formed U profiles, welded together in the centre of both column webs, which differs from boxes made from round hollow sections by cold forming. Table 1 summarizes varying parameters of all 8 specimens with calculated global and local slenderness $\bar{\lambda}_{G L}$ and $\bar{\lambda}_{\text {loc }}$. All plates were from steel grade S 355 .
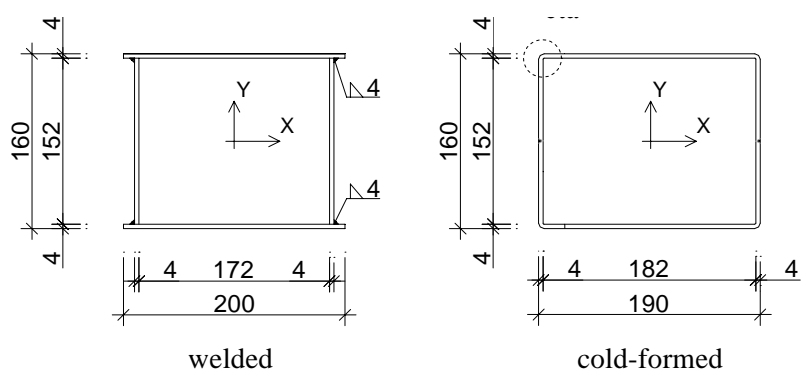

Fig. 2. Cross-section geometry for welded and cold-formed columns
Table 1. Specimen parameters for all eight full-scale tests

\begin{tabular}{c|c|c|c|c|c}
\hline \multirow{2}{*}{$\begin{array}{c}\text { Speci- } \\
\text { men }\end{array}$} & $\begin{array}{c}\text { Eccentri- } \\
\text { city in Y }\end{array}$ & $\begin{array}{c}\text { Type of } \\
\text { profile }\end{array}$ & $\begin{array}{c}\text { Buckling } \\
\text { length }\end{array}$ & \multicolumn{2}{|c}{ Slenderness } \\
\cline { 2 - 6 } & $e_{Y}[\mathrm{~mm}]$ & $\mathrm{W} / \mathrm{CF}$ & $L_{\boldsymbol{u}}[\mathrm{mm}]$ & $\bar{\lambda}_{G L}$ & $\bar{\lambda}_{\text {loc }}$ \\
\hline $\mathrm{W}-\mathrm{S}$ & 0 & $\mathrm{~W}$ & 4000 & 0.80 & 0.93 \\
\hline $\mathrm{W}-\mathrm{L}$ & 0 & $\mathrm{~W}$ & 5200 & 1.04 & 0.93 \\
\hline CF-S & 0 & $\mathrm{CF}$ & 4000 & 0.80 & 0.93 \\
\hline CF-L & 0 & $\mathrm{CF}$ & 5200 & 1.04 & 0.93 \\
\hline W-E2 & 20 & $\mathrm{~W}$ & 4000 & $0.80^{*}$ & $0.93^{*}$ \\
\hline W-E6 & 60 & $\mathrm{~W}$ & 4000 & $0.80^{*}$ & $0.93^{*}$ \\
\hline W-E20 & 200 & $\mathrm{~W}$ & 4000 & $0.80^{*}$ & $0.93^{*}$ \\
\hline CF-E6 & 60 & $\mathrm{CF}$ & 4000 & $0.80^{*}$ & $0.93^{*}$ \\
\hline
\end{tabular}

* Slenderness calculated ignoring bending effects

\subsubsection{Test set-up}

The tests were carried out in the loading machine with $15 \mathrm{MN}$ capacity. The rotation supports at the bottom and at the top provide a hinge around the weak $(x)$ axis - see Fig. 3. Special attention was paid to the introduction of eccentric loading, for which an eccentric clamping system had been developed (Fig. 3b). More transducers were set at both supports for measuring relative vertical displacements of supports (Fig. 3), in order to possibly obtain pure column contraction.
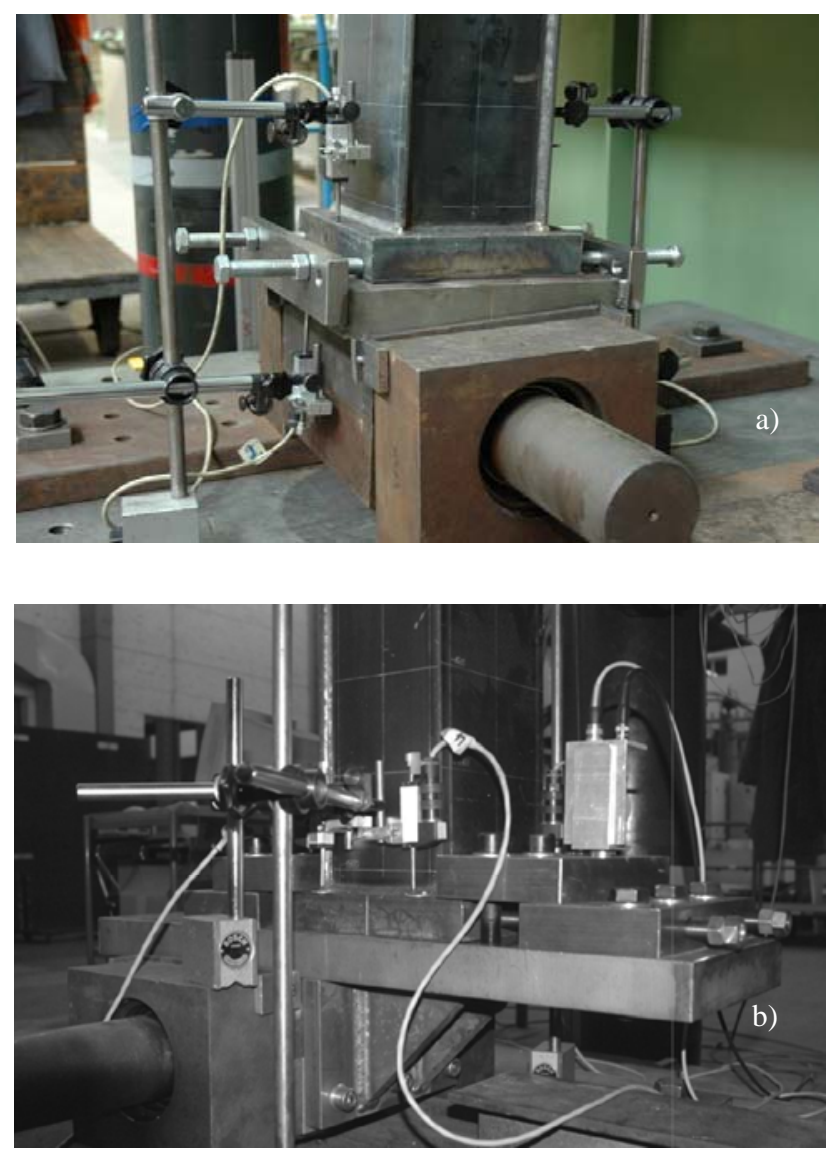

Fig. 3. Roller supports for centric (a) and eccentric (b) tests 
Lateral deformations were measured by using a measuring frame to which twelve transducers were fixed - three for each column plate (Fig. 4). This frame was attached to a special device movable along the column axis. The deformations of column middle part (in the range of $1400 \mathrm{~mm}$ with $100 \mathrm{~mm}$ vertical distances) were measured at selected measuring steps. To check possible plastification of steel, strains were measured with 48 onedimensional strain gauges placed on all four plates of column middle part.

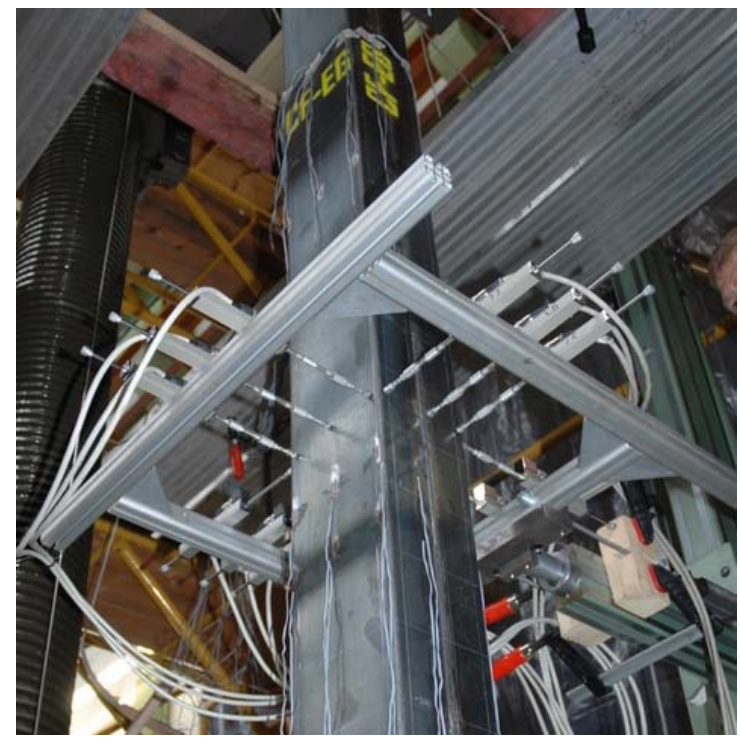

Fig. 4. Measuring frame for lateral deformations

\subsubsection{Test results}

The development of column deformations is for all tests similar: close to the maximal load a series of small local buckles appeared in the most compressive flange (Fig. 5a), followed by the development of one significant buckle (acting as a plastic hinge) close to the column mid-height shortly after the ultimate load had been reached (Fig. 5b), which led to sudden drop of the load and then the lateral displacements increased distinctively. Comparing columns of different height, both longer columns showed larger scale of global lateral displacements at the ultimate load than adequate shorter columns (e.g. $U_{z, u} / L_{u}=1 / 190$ for longer welded and 1/300 for shorter welded centrically loaded column), showing more pronounced global failure mode.

Table 2 summarizes the measured ultimate loads of all 8 columns compared to the elastic yield load with corresponding vertical displacements. For the eccentric tests the load capacity reductions compared to the comparable centric tests are also given. The maximal reduction appeared to be as high as $70 \%$. Welded and cold-formed columns with $60 \mathrm{~mm}$ eccentricity showed comparable capacity reduction. The effect of the manufacturing procedure is not clear, since in the case of shorter centrically loaded columns the welded profile possessed to some extent larger resistance than cold-formed column, while in the case of both longer columns the cold-formed column appeared to be slightly stronger than welded column.

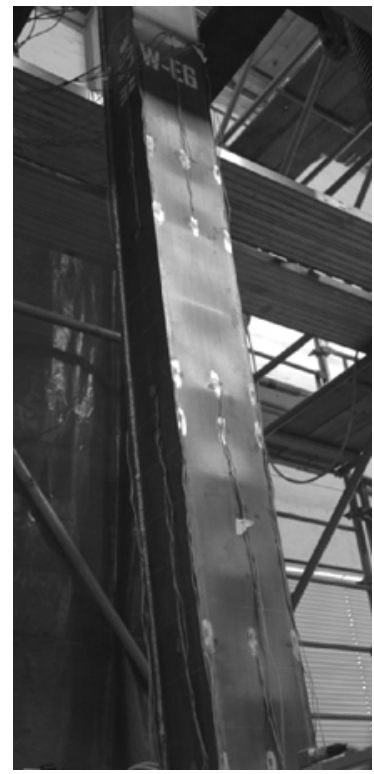

a) At the ultimate load $F_{u}$

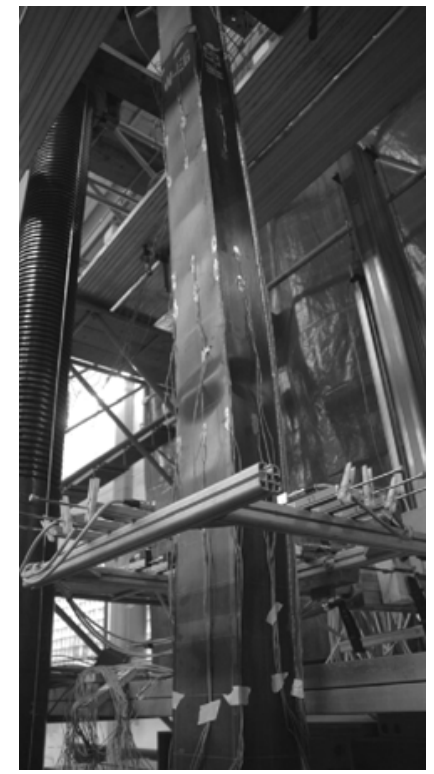

b) At later loading step
Fig. 5. Deformations of column W-E6 at two loading steps

Table 2. Measured ultimate loads $F_{u}$ and vertical displacements $U_{z, u}$ for all 8 tests

\begin{tabular}{c|c|c|c}
\hline Specimen & $F_{u} / F_{e l}{ }^{*}$ & $U_{z, u}[\mathrm{~mm}]$ & $F_{u} / F_{u, e=0}$ \\
\hline W-S & 0.671 & 5.3 & \\
\hline W-L & 0.536 & 5.6 & \\
\hline CF-S & 0.628 & 4.6 & \\
\hline CF-L & 0.581 & 5.9 & \\
\hline W-E2 & 0.539 & 4.9 & 0.802 \\
\hline W-E6 & 0.366 & 5.5 & 0.545 \\
\hline W-E20 & 0.196 & 4.1 & 0.292 \\
\hline CF-E6 & 0.318 & 3.2 & 0.506 \\
\hline
\end{tabular}

$* F_{e l}=1051.5$ or $1003.7 \mathrm{kN}$ for $\mathrm{W}$ or $\mathrm{CF}$, respectively

\subsection{Accompanying tests and measurements}

\subsubsection{Tensile tests}

For the determination of material properties of steel, four tensile tests were conducted. At two tests a few 5 minute breaks were introduced to estimate also "static" material properties. Strains in the specimen neck were measured with optical measurement and with extensometer for strains up to $2 \%$ - see Fig. 6.

Measured average yield stress $\left(f_{y}=R_{e L}=373.4 \mathrm{MPa}\right)$ is obtained 5\% higher than nominal yield stress of applied steel grade S355 and the static value is assessed as $R_{e S}=$ 351.1 MPa. For the subsequent numerical simulation, $\sigma-\varepsilon$ diagrams and their "static" values are approximated with two elastic-plastic diagrams, presented in (Pavlovčič et al. 2009). 

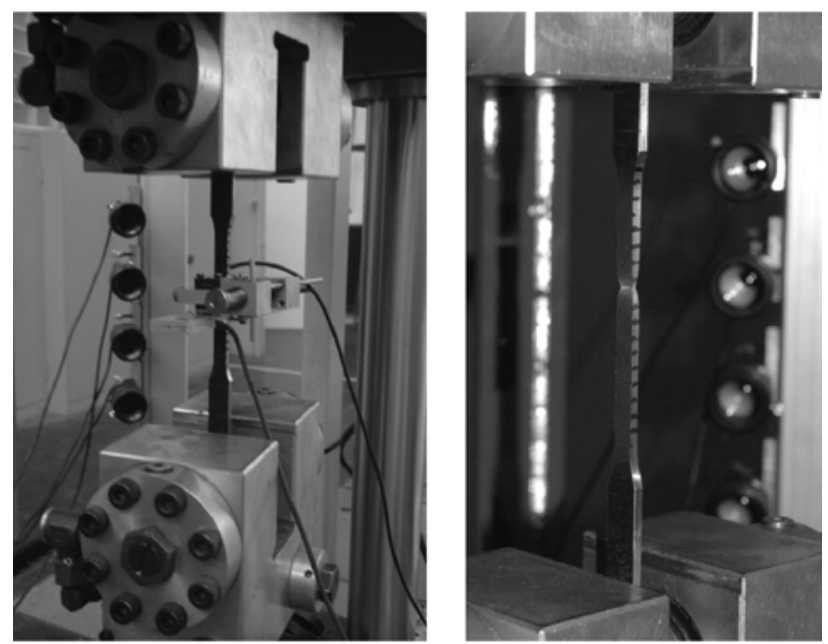

Fig. 6. Test set-up for tensile tests

\subsubsection{Residual stress measurements}

Residual stresses were measured on two different pieces of profile (cut off from columns during their fabrication), in order to assess the effect of welding or cold-forming on residual stresses and consequently on column behaviour. The sectioning method was applied - see Fig. 7. A series of one-dimensional strain gauges were glued on external and internal surface of a flange and a web (exact position presented in Pavlovčič et al. (2009)). After sawing (one transversal cut close to the strain gauges and subsequent longitudinal cuttings between them) residual stresses could be calculated from released strains.

Figs 8 and 9 show the results for the flange and web of welded profile and Figs 10 and 11 in similar way for cold-formed profile. In the case of welded flange, tensile residual stresses $\sigma_{t}$ in the range of welds expectedly reached about the level of the measured yield stress $\left(f_{y}=\right.$ $\left.R_{e L}=373.4 \mathrm{MPa}\right)$. The level of the compressed residual stresses is high (35\% of $\sigma_{t}$ in flanges and even $44 \%$ of $\sigma_{t}$ in webs) showing a significant effect of welding due to large weld-to-plate thickness ratio. In the case of coldformed profile, tensile residual stresses (also close to $f_{y}$ ) developed only in the area of welds in the middle of both webs, which yields lower compressive membrane stresses in both flanges (23\% of $\sigma_{t}$ ). Regarding stresses on both surfaces, in the case of welded profile they are almost the same, while they differ in the cold-formed profile - in the middle due to possible local buckling, but more significantly at both flange edges, where cold-forming contributes to clear stress gradient across the plate thickness.

For the purpose of numerical simulations, the measured stresses were approximated with simple constant stress distribution with stress levels as depicted in Figs 8 to 11 . The range of positive and negative stresses was determined by achieving the stress equilibrium separately for flanges and webs of welded profile and based on the whole cross section for cold-formed profile.

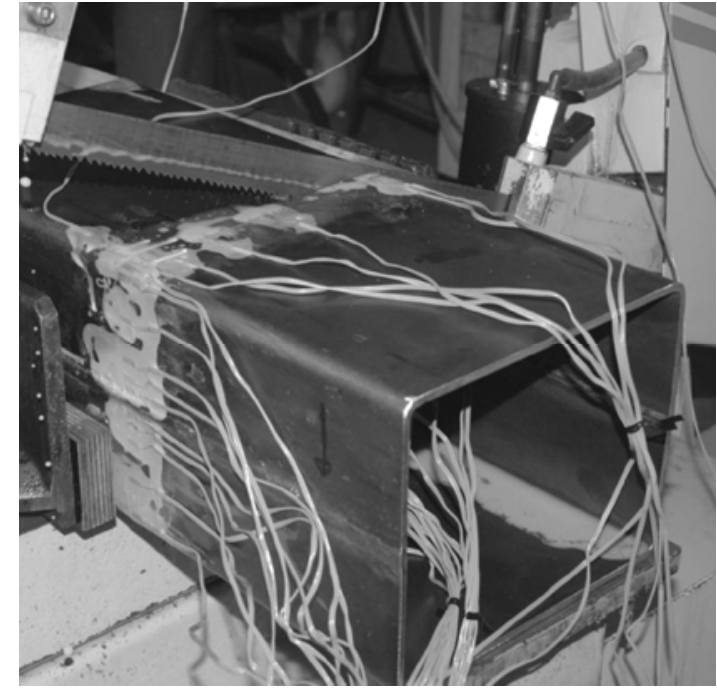

a) Transversal cut

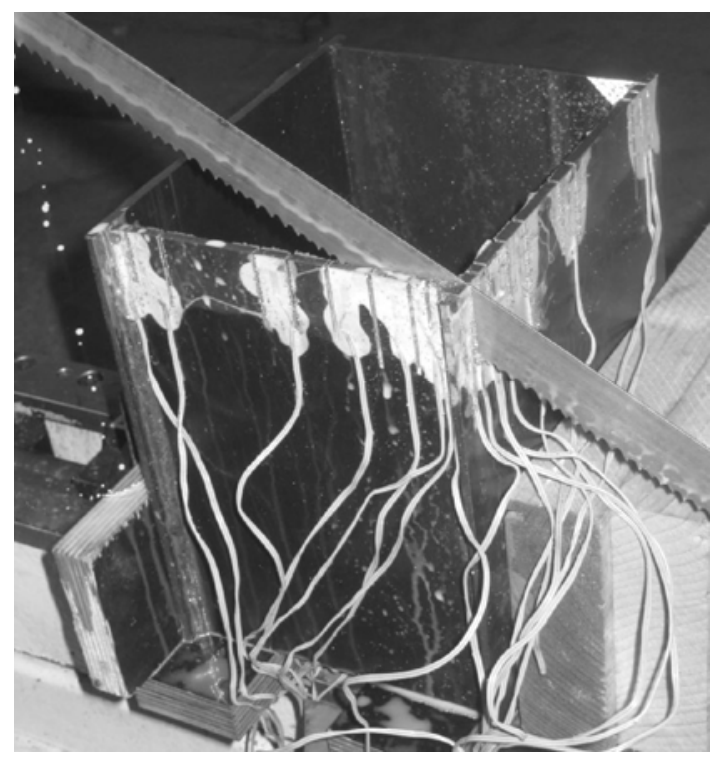

b) Longitudinal cuttings

Fig. 7. Sectioning method for residual stress measurements

\subsubsection{Measurements of initial geometric imperfections}

Before each test the initial geometry was measured along the whole column length with three transducers for each column plate. The columns were placed in the horizontal position with measured plate facing upwards. The data were recorded at each $100 \mathrm{~mm}$ step along the column length. The acquired data were then transformed to an assessed real geometry and column position during test. In the first step the plane of measured plate was mapped to the vertical position (by applying the data translation and two rotations), obtaining the imperfect column positioned vertically. In the second step the transformed column geometry was adjusted by rotation to the actual column position, measured with the measuring frame just 


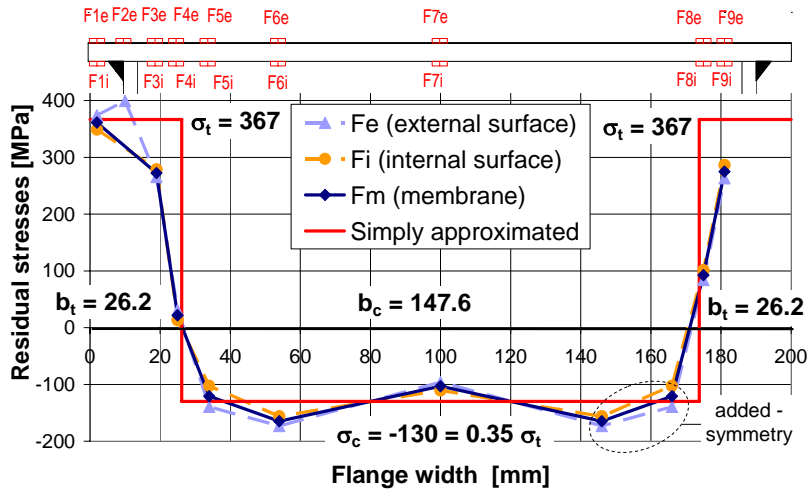

Fig. 8. Measured residual stresses in the flange of welded profile

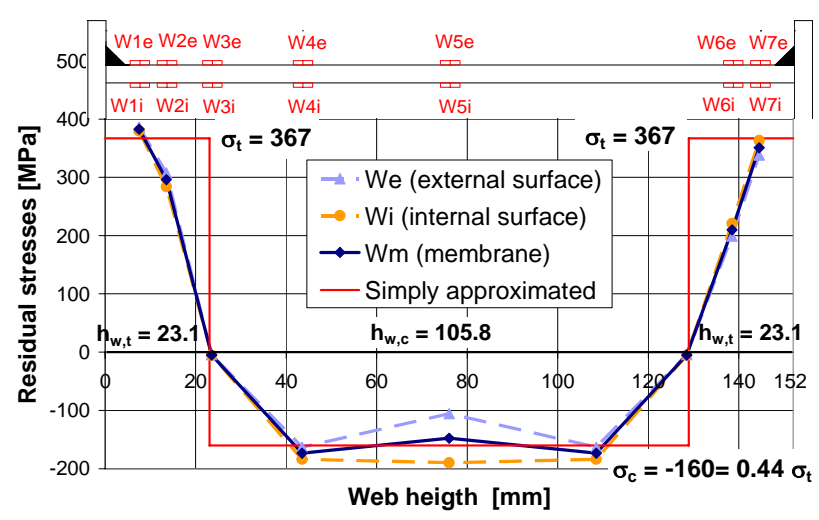

Fig. 9. Measured residual stresses in the web of welded profile

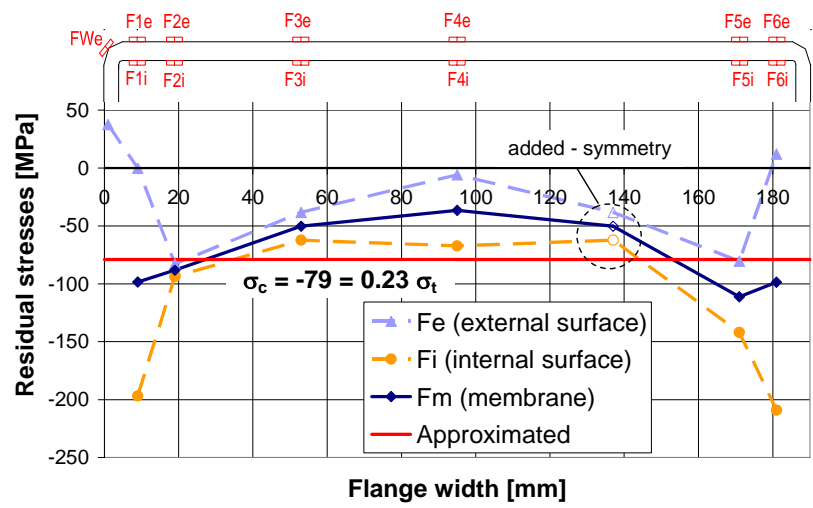

Fig. 10. Measured residual stresses in the flange of cold-formed profile

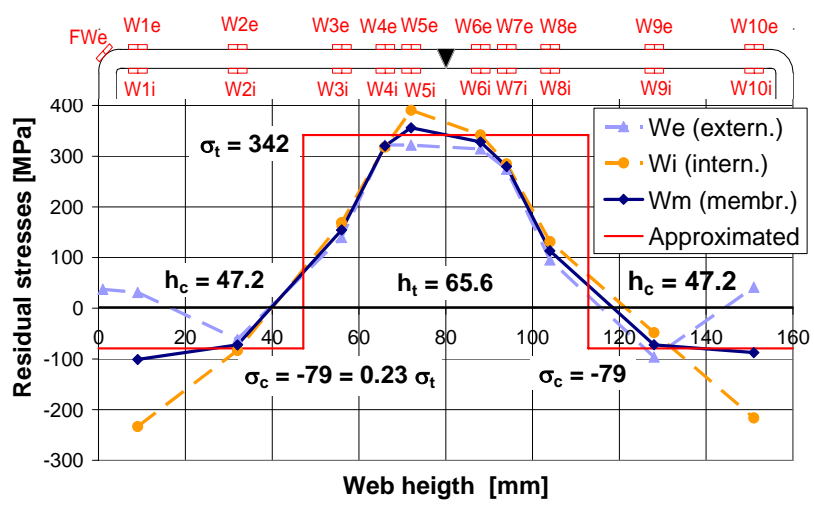

Fig. 11. Measured residual stresses in the web of cold-formed profile before the start of test (data acquired only for the column middle part). From the applied rotation the column initial inclination can be estimated and the column top eccentricity for $e_{T X}$ and $e_{T Y}$ may be assessed.

All edge measurements (left and right transducer position for each plate) were successfully fitted with a polynomial function of $6^{\text {th }}$ order $-U_{G}$. Figs 12 and 13 show pure global imperfections of all columns in both directions ( $\mathrm{Y}$ and $\mathrm{X}$ ), where column top end is set to null position. Each curve is the average of all four edge measurements. The maximal global imperfection in $\mathrm{Y}$ direction for higher columns appeared to be $4 \mathrm{~mm}$ (which is around $\mathrm{H} / 1200$ ) and $3.5 \mathrm{~mm}=\mathrm{H} / 1040$ for shorter columns. In $\mathrm{X}$ directions the global imperfections are smaller - up to H/1600. Moreover, in both figures are also

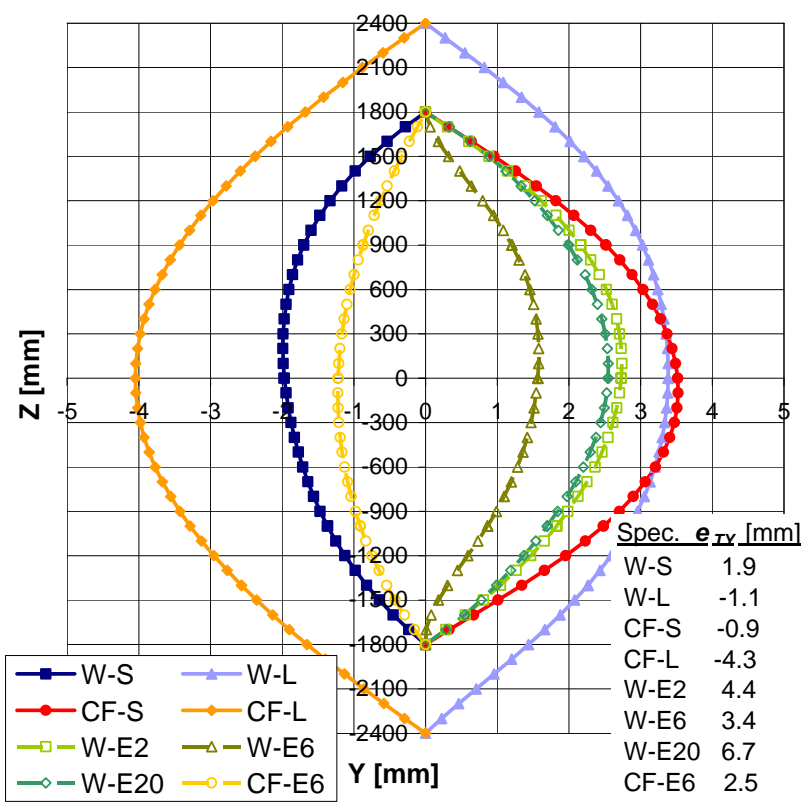

Fig. 12. Global imperfections in $Y$ (buckling) direction with assessed top eccentricities $e_{T Y}$

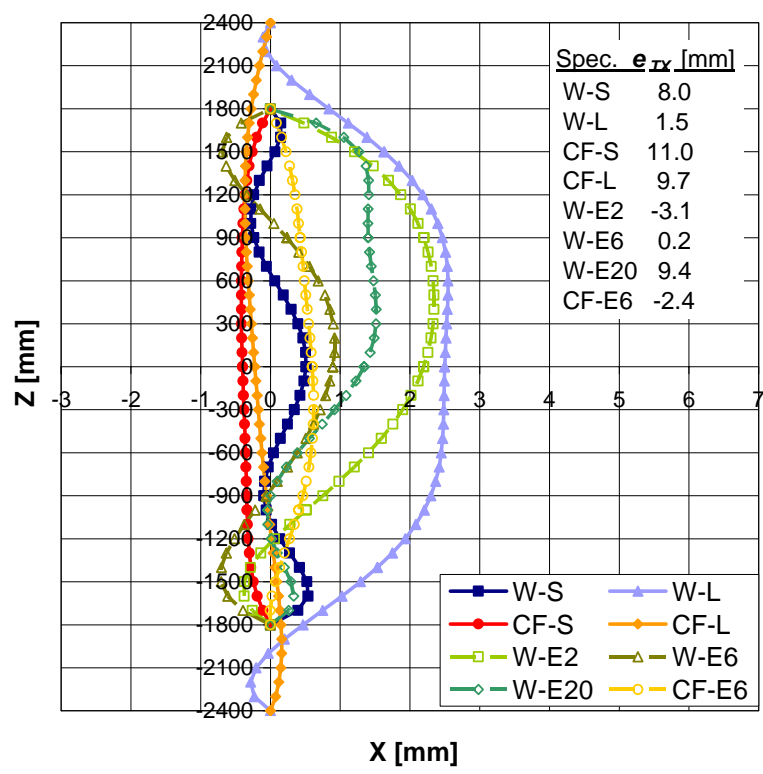

Fig. 13. Global imperfections in $X$ (lateral) direction with assessed top eccentricities $e_{T X}$ 
listed assessed top eccentricities for all specimens in both directions. It is important to note relatively high lateral column inclinations (in $\mathrm{X}$ direction) with accidental top eccentricities up to $11 \mathrm{~mm}$. Accidental top eccentricities in $\mathrm{Y}$ direction slightly reduced the planned load eccentricity for all eccentric tests.

The amplitudes of local imperfections for each plate were obtained from the difference between the measurement of the middle transducer and the average of both edge transducers. For all flanges the maximal amplitude does not exceed $0.5 \mathrm{~mm}$ (which is $c / 340$, where $c=$ $170 \mathrm{~mm}$ is the distance between webs). The relative local imperfections in the plate mid-line were successfully fitted with a polynomial function of higher orders $U_{\text {amp.loc }}$.

\section{Numerical simulation of tests}

\subsection{Numerical models}

\subsubsection{General parameters}

For the numerical simulation the nonlinear large displacement FEA was applied by using software tool ABAQUS (2007). The column geometry was modelled according to the designed mid-plane geometry with the length corresponding to the profile length: $3650 \mathrm{~mm}$ for shorter columns and $4850 \mathrm{~mm}$ for longer columns. In the case of cold formed profiles the edges were rounded with designed mid-plane radius of $7 \mathrm{~mm}$. Both end-plates and supports were simulated by coupling all degrees of freedom of the edge nodes to the reference point RP1 (at the bottom) and RP2 (at the top), both set in the axis of the rotational supports (see Fig. 14). The load eccentricity for eccentric tests was simulated by shifting the position of both reference points to $e_{Y}=[20,60,200] \mathrm{mm}$. In the case of centric tests, only rotation around longitudinal axis $\mathrm{R}_{\mathrm{Z}}$ was restricted,

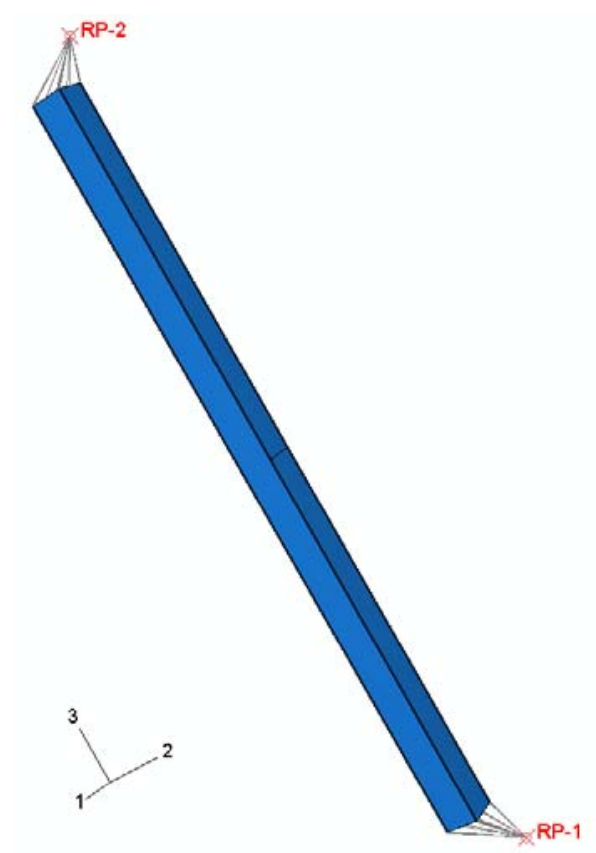

Fig. 14. Supports simulated by coupling of edge node displace-ments while in the case of eccentric tests the rotation around strong axis $R_{Y}$ was also hindered. Moreover, all displacements of the bottom reference point RP1 were restricted, while with the shifting of RP2 in the longitudinal -Z direction the loading was simulated.

The specimens were modelled with four-nodded shell elements S4R with reduced integration. The density of the mesh (see Fig. 15) was selected based on small preliminary study. To achieve better convergence for very sensitive stability problem, the integration according to the arc length method (modified Riks) was applied and for the integration through the element thickness in five section points the Simpson's rule was considered.
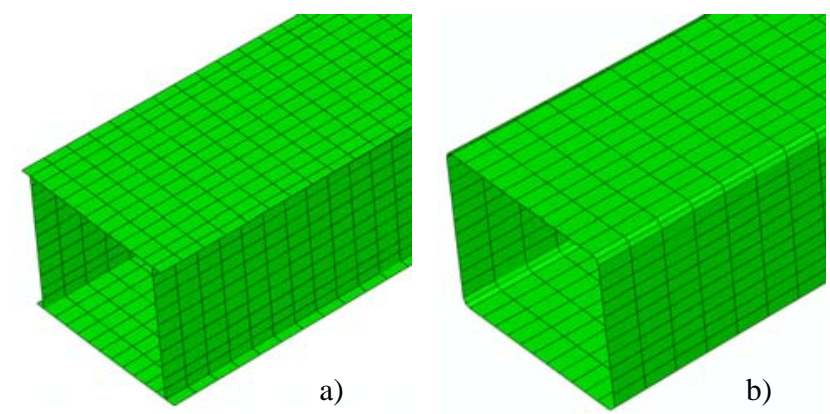

Fig. 15. Meshing of welded (a) and cold-formed (b) profiles

\subsubsection{Material models}

The elastic-plastic material model was determined based on the approximated stress-strain curves regarding the mean properties obtained from four tensile tests. Beside the "normal" approximation with $f_{y}=R_{e L}=373.4 \mathrm{MPa}$ also the approximation of "static" material properties with $f_{y}=R_{e S}=351.1 \mathrm{MPa}$ was considered. For the implementation in ABAQUS both stress-strain curves were recalculated to logarithmic plastic strains $\varepsilon_{l n}{ }^{p l}$ and true stresses $\sigma_{\text {true }}$.

\subsubsection{Implementation of initial imperfections}

The initial column inclination was simulated by implementing accidental top eccentricity, as assessed by geometrical data transformation procedure described in subchapter 2.2.3. The position of the top reference point RP2 was corrected for $-e_{T X}$ and $-e_{T Y}$, with values summarized in Figs 12 and 13.

The measured initial geometric imperfections were implemented by changing node coordinates with the use of previously defined global $\left(U_{G}\right)$ and local $\left(U_{\text {amp.loc }}\right)$ fitting functions. For each plate the global imperfections were defined with both "edge" measurements with linear interpolation and extrapolation for other nodes in plate. Additional local imperfections were applied in the shape of half cosine wave in the lateral direction with the amplitude defined with the fitting function $U_{\text {amp.loc }}$. The overall imperfect geometry was finally defined with the sum of global and local displacement functions.

Fig. 16 shows an example of the imperfect geometry for specimen $\mathrm{W}-\mathrm{S}$, where the imperfections are amplified by factor 10 . 


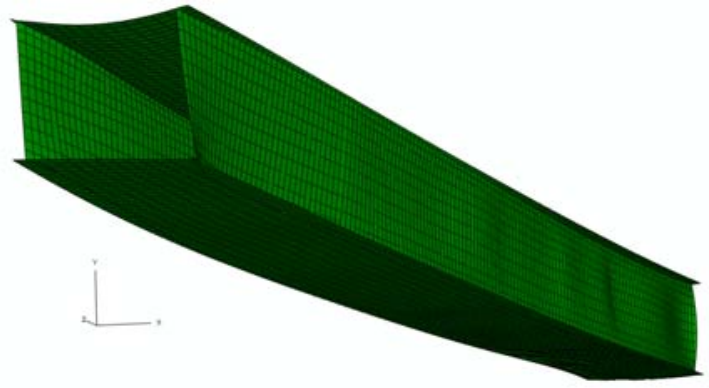

Fig. 16. Modelled imperfect geometry of specimen W-S (amplification factor 10)

The measured residual stresses were implemented by defining an initial stress condition. The simple approximation of residual stresses was considered as presented in Figs 8 to 11 for welded and cold-formed profile. The regions of tensile and compressive stresses in flanges and webs were defined by proper partitioning of the model. In order to establish an exact equilibrium state for the FE model, before each analysis an equilibrating step was performed, equilibrating stresses in one increment.

\subsection{Results of FEA simulations}

\subsubsection{Load-carrying capacities}

Figs 17 and 18 show the comparison of load-deflection curves for all centrically and Fig. 19 for all eccentrically loaded columns, obtained from test and FEA results. Vertical displacement $U_{Z}$ is regarded as column contraction. As illustration the FEA curves in Fig. 17 are plotted based on both material models $\left(R_{e L}-\right.$ "normal" and $R_{e S}-$ "static" properties). The FEA curves based on "static" material properties may be compared with fictive curves, connecting the lower points of 'measuring gaps' in test curves. With this comparison the effect of loading speed may be eliminated. The results show good agreement regarding initial stiffness (initial curve slope), shape of curves as well as load-carrying capacity, especially when "static" capacities are considered (see Fig. 17).

Table 3 summarizes the comparison of test and FEA load-carrying capacities for all 8 tests for "normal" and "static" material model. Comparable "static" ultimate capacities from tests are assessed from measured ultimate capacities multiplied by static-to-normal force ratio

Table 3. Comparison of test and FEA resistances for two material models

\begin{tabular}{c|c|c}
\hline Specimen & $F_{u, F E A, R e L} / F_{u, \text { test }}$ & $F_{u, F E A, R e S} / F_{u, \text { test }, S}$ \\
\hline W-S & 0.943 & 0.986 \\
\hline W-L & 1.042 & 1.047 \\
\hline CF-S & 1.047 & 1.055 \\
\hline CF-L & 0.913 & 0.952 \\
\hline W-E2 & 0.921 & 0.944 \\
\hline W-E6 & 0.929 & 0.970 \\
\hline W-E20 & 0.911 & $\mathbf{0 . 9 4 3}$ \\
\hline CF-E6 & 0.980 & 1.030 \\
\hline
\end{tabular}

obtained from the 'measuring gap' close to the peak load. The "normal" FEA capacities differ from the test results within 9\% and the "static" FEA capacities within only $6 \%$, which is very good agreement for the large sensitivity of load resistance to all kind of imperfections. FEA yields also more consistent results regarding the type of manufacturing, since cold-forming always leads to lower capacities in comparison to comparable welded columns.

\subsubsection{Lateral deformations}

Figs 20 and 21 shows the displacement comparison of more compressed flange mid-line of W-S and W-L

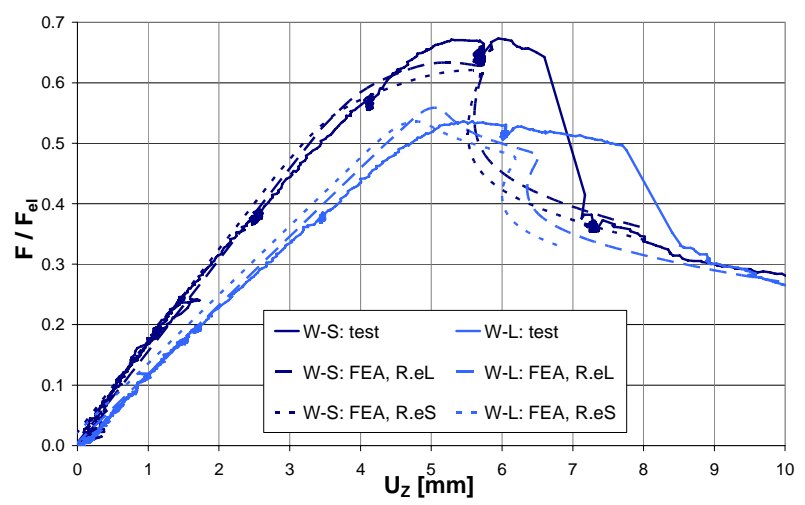

Fig. 17. Test and FEA load-deflection curves for both welded centrically loaded columns

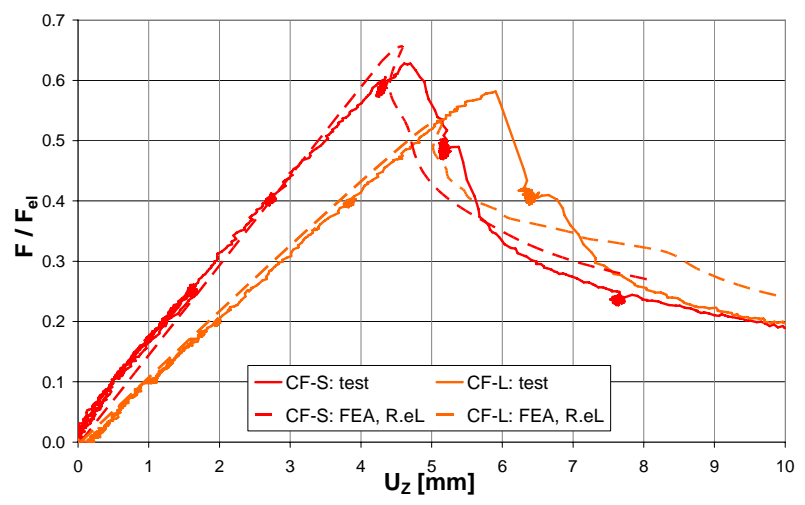

Fig. 18. Test and FEA load-deflection curves for both cold-formed centrically loaded columns

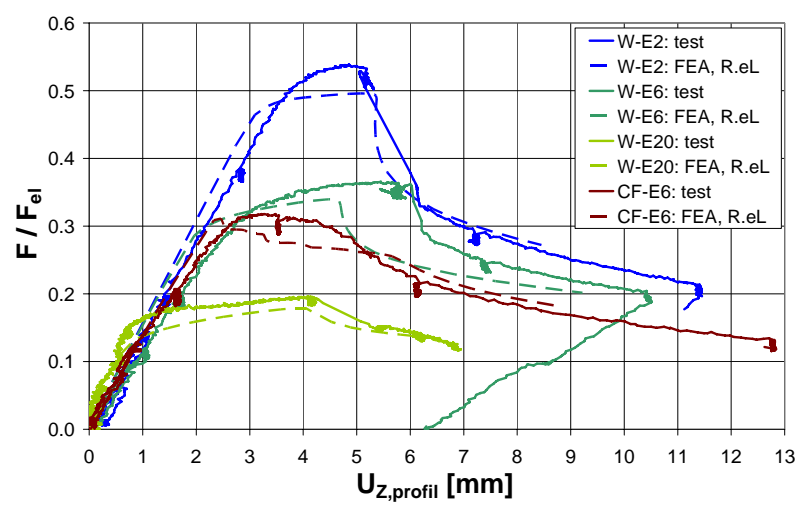

Fig. 19. Test and FEA load-deflection curves for all eccentric tests 


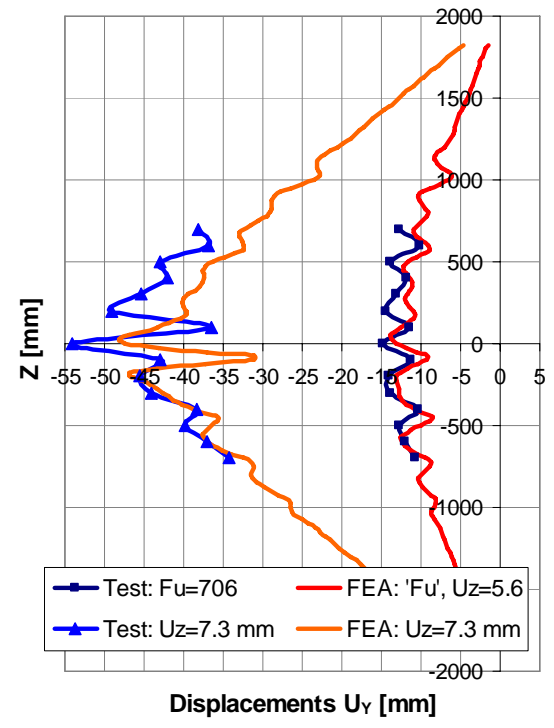

Fig. 20. Displacements of more compressed flange of W-S at the ultimate load and the last measurement

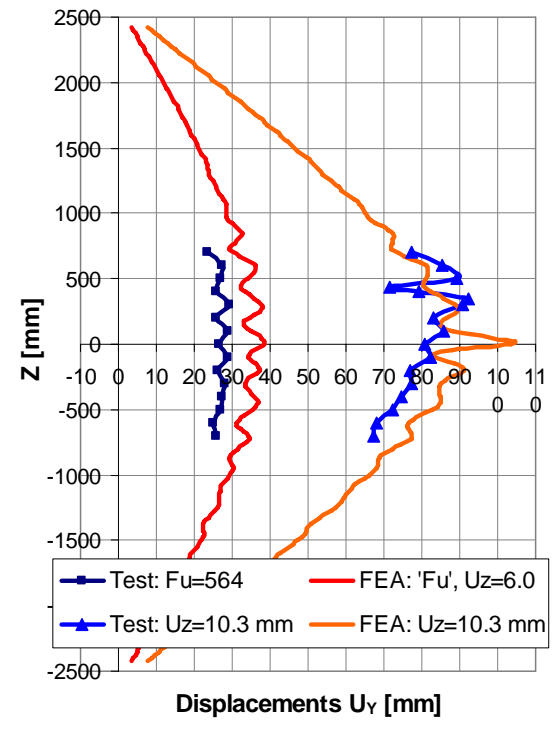

Fig. 21. Displacements of more compressed flange of W-L at the ultimate load and the last measurement

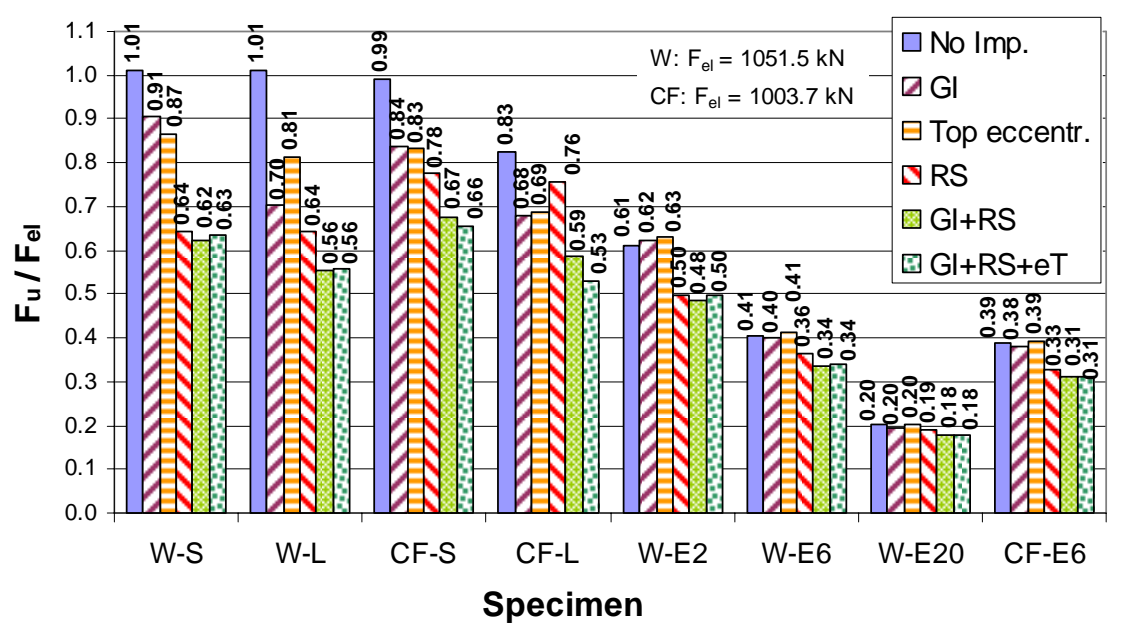

Fig. 22. Resistance sensitivity to different imperfections and their combinations

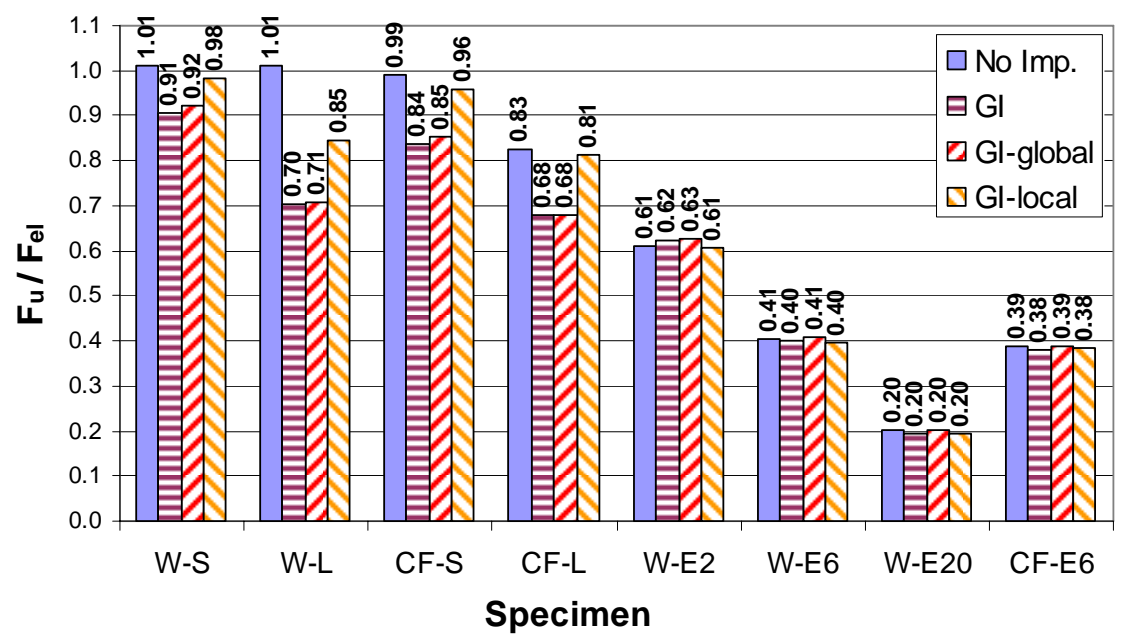

Fig. 23. Resistance sensitivity to different geometric imperfections 
specimen at the 'ultimate load measurement' and the final measurement from tests and at the comparable loading steps from FEA. Similar comparisons for other specimens are presented in (Pavlovčič et al. 2009).

The results show that global and local deformations are fairly comparable at both loading steps. The amplitudes of local displacements are in good agreement, with even similar displacement shape at the "ultimate" state. At the final measuring step significant local buckle might appear at slightly other location, since the development of a distinctive buckle is probably very sensitive to any local irregularities.

\section{Numerical study of initial imperfections}

The verified numerical models offer a possibility to study sensitivity of load resistance to each particular measured imperfection and their combinations. The following imperfection states were considered: no imperfections, with only geometric imperfections (GI, also only as global or only as local GI), with only top eccentricities (eT), with only residual stresses (RS), with geometric imperfections and residual stresses together (GI + RS) and as complete combination $(\mathrm{GI}+\mathrm{RS}+\mathrm{eT})$. Fig. 22 shows the comparison of the influence of different imperfections (GI, eT, RS) and two imperfection combinations to column capacity. In Fig. 23 the influence of geometric imperfections is divided also to only global and local geometric imperfections, all compared to the 'no imperfection' case. In all diagrams the calculated capacities are normalized with elastic (plastic) column resistance $F_{e l}$, taking into account measured $f_{y}=$ $R_{e L}=373.4 \mathrm{MPa}$. In some 'no imperfection' cases the normalized capacities exceed value 1 due to the modelled elastic-plastic material with strain hardening.

The results show that columns subjected to pure compression are very susceptible to initial imperfections with the capacity reduction up to $45 \%$ (W-L). On the other hand, the planned load eccentricity reduces the column elastic resistance already by itself (61\%, 41\% and $20 \%$ of $F_{e l}$ for $e_{Y}=20,60,200 \mathrm{~mm}$, respectively) and further reduction due to imperfections gets smaller with the increase of planned eccentricity (reduction by $19 \%$, $16 \%$ and $11 \%$ for welded columns with $e_{Y}=20,60$, $200 \mathrm{~mm}$, respectively).

Among all independent imperfections, the residual stresses have the largest influence (with the exception of CF-L), with the capacity reduction up to $37 \%$ (19\% to 5\% for the eccentric tests). Geometric imperfections and accidental top eccentricities have comparable impact, which is $11 \%$ to $31 \%$ for the centric tests and only up to 2.3\% for the eccentric tests (accidental eccentricities act favourably). In the case of geometric imperfections in all centrically loaded columns the global imperfections have clearly prevailing influence and the local geometric imperfections contribute to almost negligible further capacity reduction (see Fig. 23). In the case of the eccentric tests all types of geometric imperfections practically have no effect.

When combining different imperfections, further reduction appeared to be of a smaller scale (up to $18 \%$ of further reduction) compared to the effect of independent imperfections. Moreover, when comparing GI+RS and GI+RS+eT combinations (Fig. 22), for both centrically loaded welded columns the additional top eccentricities even slightly increase the column capacities.

\section{Conclusions}

The paper presents some results of the present research on combined global and local instability problem of slender thin-walled box columns under compression and bending. In the first part 8 full-scale tests are presented, where the varying parameters are column length (global slenderness), manufacturing procedure (welding and cold-forming) and loading condition with centric and eccentric compression. The columns failed as planned: shorter centrically loaded columns in combined local and global buckling and all the rest in more pronounced global buckling mode. For the subsequent numerical simulations, very important results were obtained from accompanying material tests and measurements of different initial imperfections. It is worth pointing out that very sensitive measurement of residual stresses appeared to be successful, as it resulted in clear stress distribution for welded and for cold-formed type of profiles.

The FEA simulation of tests was carried out according to nonlinear large displacement theory by using FEA tool ABAQUS (2007). Two types of elastic-plastic material were modelled based on measured material properties. Special attention was paid to careful implementation of all types of measured initial imperfections: residual stresses, geometric imperfections and column inclination. The results of FEA simulations show good agreement with the test results: agreement in load-carrying capacities was reached within only $6 \%$ and the deformations resemble both in shape and amplitudes.

On verified numerical models the sensitivity of column resistance to each particular measured imperfection and their combinations was studied. Among different imperfections the residual stresses appeared to have prevailing impact, reducing column capacity up to $37 \%$. In the case of centric tests the complete imperfection combination reduces the resistance up to $45 \%$ regarding initially perfect column. With the increase of designed load eccentricity the imperfections have smaller influence (reduction by 11 to $19 \%$ ), since the load eccentricity, i.e. the introduction of additional bending moment, reduces the column elastic resistance markedly already by itself. From these results it can be concluded that for the accurate numerical simulation of elements in compression it is unavoidable to implement different initial imperfections very carefully based on real data, provided from different accompanying tests and measurements.

\section{Acknowledgements}

Acknowledgement is made to the German Federation of Industrial Research Associations „Otto von Guericke“ e.V. (AiF) and the German Research Committee for Steel DASt for funding AiF-Nr. $15025 \mathrm{~N}$ research project and to Slovenian Research Agency ARRS for the financial support of postdoc project Z2-0826. We are also very 
gratefull to our industry partners for their support, especially Haller Stahlbau, Villingen-Schwenningen for the supply of material and the fabrication work done preparing the test specimens. Their support is gratefully acknowledged.

\section{References}

ABAQUS, Version 6.7, Dassault Systèmes, 2007.

Brune, B. 2000. Biegeknicken von druck- und biegebeanspruchten Stahlbauteilen mit Beulschlanken Blechen - Ein Gesamtstabilitätsproblem [Buckling of thin-walled steel elements under compression and bending - a coupled instability problem], Bericht aus dem Fachgebiet Stahlbau, Mitteilung Nr. 23 [Report from the field of Steel Structures, No. 23]. Dortmind: University of Dortmund. 75 p.

Degée, H.; Detzel, A.; Kuhlmann, U. 2008. Interaction of global and local buckling in welded RHS compression members, Journal of Constructional Steel Research 64(7-8): 755765. doi:10.1016/j.jcsr.2008.01.032

Detzel, A. 2006. Zum Gesamtstabilitäts-problem geschweißter Rechteckquerschnitte unter Druckbelastung [Coupled instabilities of thin-walled welded box sections under comp- ression], Ph.D. thesis, Stuttgart: Institute for Structural Design, University of Stuttgart. 137 p.

EN 1993-1-1 Design of steel structures. General rules and rules for buildings. European committee for standardization. Brussels, 2005. $91 \mathrm{p}$.

EN 1993-1-5, Design of steel structures. Plated structural elements. European committee for standardization. Brussels, 2005. 53 p.

Kuhlmann, U.; Detzel, A. 2004. Competitive steel and composite bridges by improved steel plated structures, WP 3.3 Test report, ComBri/USTUTT-44, Internal Report, Stuttgart: Institute for Structural Design, University of Stuttgart.

Pavlovčič, L.; Froschmeier, B.; Kuhlmann, U. 2009. Welded and cold formed box columns under compression and bending. Test report, Stuttgart: Institute for Structural Design, University of Stuttgart. $138 \mathrm{p}$.

Rusch, A. 2000. Tragfähigkeit von beulgefährdeten, normalspannungs-beanspruchten I-Profilen [Load carrying capacity of thin-walled I-sections subjected to normal stresses], Ph.D. thesis, Berlin: Technical University of Berlin. 2000, 231 p.

\section{LIAUNOSIOS LENKIAMOS IR GNIUŽDOMOS PLONASIENĖS DE்ŽINIO SKERSPJŪVIO KOLONOS}

\section{Pavlovčič, B. Froschmeier, U. Kuhlmann, D. Beg}

S a n tra k a

Straipsnyje nagrinėjami liaunujų dėžinio skerspjūvio kolonu̧ jautrių abiejų tipų nepastovumui - bendrajam klupumui pagal Eulerị ir plieninių plokštelių vietiniam klupumui, eksperimentai. Buvo atlikti aštuoni centriškai ir ekscentriškai gniuždomų virintinio ir šaltai lankstyto skerspjūvio įvairaus liaunio kolonų natūriniai bandymai. Siekiant nuodugniai atlikti skaitini bandymų modeliavimą, taip pat bandymu nustatytos mechaninės plieno savybės ir kruopščiai išmatuoti visi pradiniai geometriniai nuokrypiai ir liekamieji ittempiai. Skaitinio modeliavimo baigtiniu elementų metodu ir natūriniu bandymų rezultatai nedaug skiriasi. Tikrinamuoju skaitiniu modeliu buvo nagrinètas įvairių pradiniu geometrinių netikslumų poveikis.

Reikšminiai žodžiai: liaunosios kolonos, děžiniai skerspjūviai, šaltai lankstyti profiliuočiai, pastovumas, klupumas, bandymai, baigtinių elementų metodas, skaitinis modeliavimas, pradiniai nuokrypiai, liekamieji įtempiai.

Luka PAVLOVČIČ is a lecturer of steel structures at the University of Ljubljana, Faculty of Civil and Geodetic Engineering. He was a member of Scientific Committee for $5^{\text {th }}$ European Conference on Steel and Composite Structures - Eurosteel 2008. His research activities are mainly focused on different stability problems of plated structures, but also on seismic protection systems and optimization of steel structures.

Bernadette FROSCHMEIER is scientific researcher at the Institute of Structural Design at the chair of Professor Kuhlmann at the University of Stuttgart. In her research projects she deals with different stability problems of members and plated structures.

Ulrike KUHLMANN is professor for Steel, Timber and Composite Structures and head of the Institute of Structural Design at the University of Stuttgart, Faculty of Civil Engineering. She is chairperson of Eurocode 3 Committee CEN TC250 SC3 and member of various code committees and professional groups e.g. member of ECCS Technical Committees TC 8 Stability, TC 6 Fatigue and chairperson of TWG 8.3 Plate Buckling.

Darko BEG is a professor of steel structures at the University of Ljubljana, Faculty of Civil and Geodetic Engineering. He is a member of Eurocode 3 Committee CEN TC250 SC3 and three ECCS Technical committees: TC 8 Stability, TC10 Connections and TC13 Seismic design. His research activities are focused on stability of plated structures, high strength steel and connections in steel structures. 